\title{
Diurnal frugivores on the Bromeliaceae Aechmea depressa L.B. Sm. from Northeastern Brazil: the prominent role taken by a small forest primate
}

\author{
Talita Fontoura $^{1,6}$, Eliana Cazetta ${ }^{1}$, Wander do Nascimento ${ }^{1}$, Lilian Catenacci ${ }^{2,3}$, \\ Kristel De Vleeschouwer ${ }^{3,4}$ \& Becky Raboy ${ }^{3,5}$ \\ ${ }^{1}$ Departamento de Ciências Biológicas, Universidade Estadual de Santa Cruz - UESC, \\ Rod. Ilhéus-Itabuna, Km 16, CEP 45650-000, Ilhéus, BA, Brasil \\ ${ }^{2}$ Programa de Pós-graduação em Zoologia, Departamento de Ciências Biológicas, \\ Universidade Estadual de Santa Cruz - UESC, Rod. Ilhéus-Itabuna, Km 16, CEP 45650-000, Ilhéus, BA, Brasil \\ ${ }^{3}$ Instituto de Estudos Sócio Ambientais do Sul da Bahia, Rua Araujo Pinho, n. 72, $3^{\circ}$ andar, \\ Centro, CEP 45653-145, Ilhéus, BA, Brasil \\ ${ }^{4}$ Centre for Research and Conservation, Royal Zoological Society of Antwerp, Koningin Astridplein, 26, \\ B-2018, Antwerp, Belgium \\ ${ }^{5}$ Smithsonian Conservation Biology Institute, 3001, Connecticut Ave. NW, Washington, DC 20008, USA \\ ${ }^{6}$ Corresponding author: Talita Fontoura,e-mail: talita_fontoura@uol.com.br
}

FONTOURA, T., CAZETTA, E., NASCIMENTO, W., CATENACCI, L., DE VLEESCHOUWER, K. \& RABOY, B.E. Diurnal frugivores on the Bromeliaceae Aechmea depressa L.B. Sm. from Northeastern Brazil: the prominent role taken by a small forest primate. Biota Neotrop. 10(4): http://www.biotaneotropica.org.br/ v10n4/en/abstract?short-communication+bn02710042010.

\begin{abstract}
Little is known about frugivory of epiphytes. We investigated diurnal frugivores consuming Aechmea depressa, an endemic species from Southern Bahia, Brazil, through 67 hours of observation on three fruiting individuals. Infructescences were visited for $2 \%$ of the time and only by golden-headed lion tamarins (GHLTs; Leontopithecus chrysomelas). Aechmea depressa invests on physical defense to retain fruits for prolonged periods, however, GHLTs used their small size and dexterity to remove rigid bracts and extract fruits from the infructescence. Prior studies indicate GHLTs disperse Aechmea seeds. Given the low visitation rates and probability that few frugivores successfully manipulate A. depressa fruits, we suggest that GHLTs are extremely important to maintaining the populations of this bromeliad species.
\end{abstract}

Keywords: Atlantic Rainforest, epiphyte, golden-headed-lion tamarin, Leontopithecus chrysomelas.

FONTOURA, T., CAZETTA, E., NASCIMENTO, W., CATENACCI, L., DE VLEESCHOUWER, K. \& RABOY, B.E. Frugívoros diurnos de Aechmea depressa L.B. Sm. (Bromeliaceae) do Nordeste do Brasil e o papel proeminente de um pequeno primata florestal. Biota Neotrop. 10(4): http://www.biotaneotropica.org.br/v10n4/ pt/abstract?short-communication+bn02710042010.

Resumo: Pouco se sabe sobre a frugivoria em plantas epífitas. Nós investigamos os frugívoros diurnos de Aechmea depressa, uma espécie endêmica do Sul da Bahia através de 67 horas de observação dos frutos de três indivíduos. As infrutescências foram visitadas em 2\% do tempo somente por micos-leão-da-cara-dourada (MLCD; Leontopithecus chrysomelas). Aechmea depressa investe na defesa física para reter seus frutos por períodos prolongados entretanto, o MLCD utiliza seu pequeno tamanho e extrema destreza para remover as brácteas rígidas e extrair os frutos da infrutescência. Estudos prévios indicam que os MLCDs dispersam sementes de espécies de Aechmea. Baseando-se na baixa taxa de visitação e na probabilidade de que poucos frugívoros manipulem adequadamente os frutos de $A$. depressa, nós sugerimos que os MLCD sejam extremamente importantes para manter as populações desta espécie de Bromeliaceae.

Palavras-chave: Floresta Atlântica, epífita, mico-leão-da-cara-dourada, Leontopithecus chrysomelas. 


\section{Introduction}

Bromeliaceae is the second most numerous plant family of epiphyte species (Gentry \& Dodson 1987). In the Atlantic forest, the high representation of epiphytes of this family is exemplified in surveys conducted in the northeastern region of this biome. In the extreme northeastern region, $65.1 \%$ of the 86 sampled bromeliad species were epiphytes (Siqueira Filho \& Tabarelli 2006). In the mountainous region of Southern Bahia, the epiphytism among bromeliads is extreme, representing 100\% of the 53 inventoried species (Amorim et al. 2009). In addition to the high representation of epiphytic bromeliads in this biome, this life form is known to constitute an important resource for various canopy-dwelling forest organisms (Nadkarni \& Matelson 1989). For example, in relation to pollination, hummingbirds are the principal pollinators of this family of plants (Sazima et al. 2000) consuming the nectar of diverse epiphyte species (see Fischer \& Araújo 1995, Benzing 2000, Sazima et al. 2000). The canopy bromeliads are also important foranging sites for golden-headed-lion-tamarins (GHLTs; Leontopithecus chrysomelas Kuhl). They spend a large proportion of their prey foraging time in the rosettes of these plants (Rylands 1989, Raboy \& Dietz 2004). However, the utilization of fruits produced by epiphytic bromeliads has rarely been investigated (Nadkarni \& Matelson 1989, Cestari \& Pizo 2008, Cestari 2009) and the scarce data indicate that birds are the main frugivores.

Epiphytic bromeliads that produce fruits are especially prominent in the tree crowns of the forest fragments in Southern Bahia, forming clusters in the bifurcations of large trees. Some rosettes can reach up to two meters in width. In most cases, these epiphytic bromeliads are represented by the genera Aechmea and Hohenbergia (Alves 2005). Several aspects contribute to the lack of observational data on these epiphytes. Firstly, they are often established on trees over four meters height. Secondly, some species have a short scape supporting the infructescence, which remain covered by leaves extending beyond the length of the infructescence. In addition, some members of Aechmea subgenus Chevaliera have hidden fruits buried within the infructescence and covered by a hard floral bract with a serrate margin or pungent apex (Smith \& Downs 1979, Sousa et al. 2008). At the fruiting period, fruits are totally or partially hidden by floral bracts (T. Fontoura pers. obs.).

Little is known about the frugivores that consume Aechmea fruits from Southern Bahia with the exception of golden-headed-liontamarins (GHLTs; Leontopithecus chrysomelas Kuhl), a species which has been documented to consume Aechmea fruits (Raboy \& Dietz 2004, Cardoso 2008, Catenacci 2008, Guidorizzi 2008) and disperse their seeds (Cardoso 2008, Catenacci et al. 2009). Germination tests indicated that after ingestion by GHLTs, seeds of Aechmea had a greater likelihood of germinating and decreased time to germination than seeds that did not pass through the digestive tract of this primate (Catenacci et al. 2009). More recently field observations revealed that one of the consumed species is A. depressa L.B. Sm., a member of Chevaliera subgenus (T. Fontoura pers. obs.).

Our study is the first investigation of diurnal frugivores consuming A. depressa to determine: i) diurnal frugivores; ii) the behavior necessary to consume the protected fruits of this species; and iii) the visitation and fruit removal rates. In addition, we discuss the implications of the fruit's morphological characteristics, and the GHLTs morphological and behavioral characteristics necessary to the utilization of the fruits of this epiphytic species.

\section{Methods}

\section{Study area}

This study was conducted in Fazenda Cabana da Serra/Incon, adjacent to the Una Biological Reserve (UBR). UBR is located approximately $40 \mathrm{~km}$ South of Ilhéus, Bahia, Brazil (15 11'26” S and $39^{\circ} 02,30^{\prime \prime} \mathrm{W}$ ) in a region characterized by forest fragments of diverse sizes interspersed within a matrix of cattle pasture, rubber tree, piaçava palm, and shade-cocoa plantations. Vegetation in this region is classified as higrophilous Southern Bahian forest and is included in the climatic region of Af from Köppen. The mean rainfall is $1800 \mathrm{~mm} /$ year with no dry season although one to three rainless months were registered from December to March (Mori et al. 1981, Thomas et al. 1998).

\section{The species}

Aechmea depressa belongs to the subgenus Chevaliera. Its inflorescence is simple and capitulated with a short scape $(13-20 \mathrm{~cm})$ covered by rigid and imbricate bracts, and the inflorescence axis (or rachis) is short and robust (Sousa et al. 2008). Flowers are sessile, arranged polystichously subtended by a rigid floral bract and are found in February, April and July (Canela et al. 2003). However, no phenological study is available for A. depressa or other Chevaliera species. Oblong baccate fruits are pink to reddish, with persistent acute sepals. The fruit may reach ca. $6 \mathrm{~cm}$ long and $4 \mathrm{~cm}$ wide, including $2 \mathrm{~cm}$ long sepals (Figure 1). Field observations revealed that seeds are oblong to ovoid in shape, casteneous colored, 3 to $5 \mathrm{~mm}$ long, and $2 \mathrm{~mm}$ width. This species is endemic to southern Bahia (Canela et al. 2003) and it is found in the canopy of forested areas and cocoa plantations.

\section{Field observations}

Three fruiting bromeliads were observed between May and June 2007. These individuals were inserted in clusters of bromeliads on two host trees within a shaded-cocoa plantation. The first cluster was approximately $7 \mathrm{~m}$ above the ground and the second one was approximately $15 \mathrm{~m}$.

Sixty-seven hours of observation were conducted over 10 days between 5:00 to 11:00 hours from a distance of more than $40 \mathrm{~m}$ to minimize the potential interference with the animals' normal
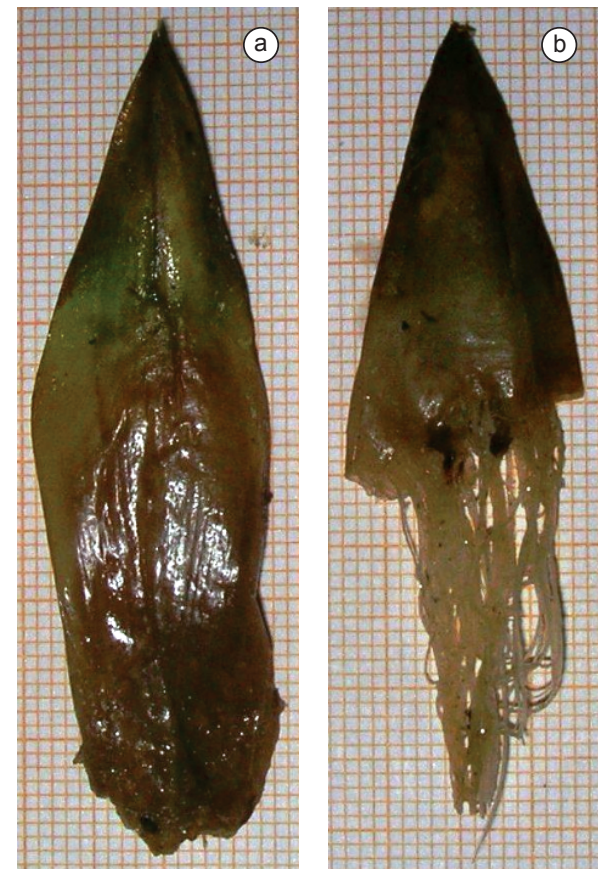

Figure 1. Discarded fruit found on the forest floor beneath the A. depressa focal clusters. a) The entire fruit; and b) the fruit with basal area removed by the lion tamarins. 
behaviors. A single person conducted focal observations (Galetti et al. 2003) on infructescences of A. depressa at the same time using binoculars to see details more clearly. During observations, all occurrences of fruit visitation were noted. The following data were registered: visiting animal species, time spent in the bromeliad, and how fruits were manipulated and consumed by animals. Additional frugivore behavior was noted ad libitum (Altman 1974) for animals in proximity to the clusters. After the focal observation, we conducted daily counts on intact and consumed fruits found on the forest floor underneath the A. depressa clusters. Total rates of fruit removal were calculated dividing the number of completely consumed fruits by the number of days of observation.

\section{Results}

Eleven visits from frugivores were registered during the study, all by one animal species, the golden-headed lion tamarin. In $81.8 \%$ of the visits, one or two lion tamarins approached the infructescence to eat fruits and in one case $(9.1 \%)$ all group members ( $\mathrm{n}=6$ individuals) went to the bromeliad. In order to remove the fruit, the lion tamarins positioned themselves within the interior of the rosette to reach the infructescence, stood in a bipedal or cantilevered position, and used their hands, mouth and teeth to pull the rigid floral bract and take out the fruit from the interior of the infructescence holding the sepals. After successful removal and fruit consumption, the sepals were discarded on the forest floor. Immature fruits were also removed but then immediately discarded by the lion tamarins. We noted foodsharing of a fruit by an adult female to an infant. We also observed scent-marking to the side of the bromeliad. Antagonistic behaviors between group members were not observed during the visits.

The total time GHLTs spent consuming fruits was 74 minutes ( $1.84 \%$ of the total observation time) and the average time of fruit manipulation was 6.7 minutes (varying from 2-16 minutes). In total, 145 fruits or fruit sepals were counted on the forest floor, $112(77.2 \%)$ with seeds completely removed and 33 (22.8\%) with some amount of seeds remaining in the discarded portions.

\section{Discussion}

The only observed frugivore eating $A$. depressa fruits was the golden-headed lion tamarin primate. This is an intriguing result due to the presence of 32 frugivorous bird species already recorded in UBR and surrounding forest fragments in morning observations (Faria et al. 2006) which could act as potential frugivores of this bromeliad species. Apparently, A. depressa fruit traits are not attractive to a considerable number of morning frugivorous birds. Given the low visitation rate (11 visits in 67 hours), longer-term observations are necessary to investigate which other frugivores are also consuming fruits of this and other Chevaliera species occurring in the region.

As far as we know, no other study investigated the visitation rate of Bromelioideae fruits and no study with fruit consumption by primates found low visitation rates (see Balcomb \& Chapman 2003, Ratiarison \& Forget 2005, Gross-Camp et al. 2009). Therefore, our extremely low visitation rates ( 11 visits in 67 hours) can be compared with a distinct group of fruits, namely, the mimetic fruits. These fruits have vividly colored seeds or fruits and do not provide nutritional reward for the potential disperser (Peres \& van Roosmalen 1996, Galetti 2002). The absence of nutritional reward coupled with the presence of secondary compounds in the pulp are responsible for the low removal rates in mimetic species (Galetti 2002, Guimarães et al. 2003). Nevertheless, these chemical characteristics do not seem to be the case of A. depressa fruits. As far as we know, data on the chemical composition of $A$. depressa are inexistent, however, conjunct analyses of Aechmea spp. fruits revealed that they are relatively rich in carbohydrates (Catenacci 2008). This suggests that for this bromeliad, amount of nutrients are not the key factor in determining fruit removal rates but the physical defense. The unexposed and protected fruits are strategies to retain fruits in an intact condition for a prolonged period which might be advantageous for plants that depend on rare or unreliable seed dispersers. The behavior of GHLTs answers Benzing's (2000) inquiry about which animal species would have the capacity to extract fruits from Chevaliera species, which he described as having "berries with hard, sharp apices stubbornly embedded in equally resistant stem tissue". Our field observations revealed that GHLTs overcome the physical challenges of reaching and removing A. depressa fruit by using an extreme manual dexterity and small flexible bodies. In particular, GHLTs have evolved long slender fingers adapted to manipulative foraging for hidden and embedded animal prey (Bicca-Marques 1999). This same characteristic is also likely helpful in extracting $A$. depressa fruits as well. No infants were observed directly removing fruits, neither in this study nor in the authors' past observations of GHLTs extracting fruit from bromeliads. The difficulty with which infants and younger lion tamarins have in extracting $A$. depressa fruit, in contrast to simple berries or drupes on other plant species, attests to the level of skill necessary to remove the $A$. depressa fruits.

Our study evaluated only diurnal frugivory in a short-term observation however, the low visitation rate, number of fruits consumed, potential absence of other diurnal frugivores, and low probability that other frugivores present enough ability to manipulate and disperse A. depressa seeds suggest that GHLTs are extremely important to the maintenance of these bromeliad populations. It is likely that the long term success of A. depressa (and possibly other members of the subgenus) in Southern Bahia depends on the continued persistence of GHLTs in the region. However, the GHLT range is declining with local imminent extinctions (Raboy et al. 2010), and few forest patches are expected to support viable GHLT populations in the long term without significant conservation action (Zeigler et al. 2010).

\section{Acknowledgements}

The Universidade Estadual de Santa Cruz (UESC) provided funding for this project with additional infrastructure support from Projeto Mico Leão-da-Cara-Dourada. Talita Fontoura, Wander do Nascimento and Becky Raboy had permission to conduct field work under the IBAMA licenses $\mathrm{N}^{\circ} 178 / 2006,12714-1$ and with additional approval from the owners of Fazenda Cabana da Serra/Incon. We are grateful to field assistants Gilvan Gomes Mota and Jiomário dos Santos Souza for helping us locate the focal clusters of A. depressa under observation in this study.

\section{References}

ALTMANN, J. 1974. Observational study of behavior: sampling methods. Behaviour 49:227-267.

ALVES, T.F. 2005. Distribuição geográfica, forófitos, espécies de bromélias epífitas nas matas e plantações de cacau da região de Una, Bahia. $\mathrm{PhD}$ Dissertation, Universidade Estadual de Campinas, Campinas.

AMORIM, A.M., JARDIM, J.G., LOPES, M.M.M., FIASCHI, P., BORGES, R.A., PERDIZ, R.O. \& THOMAS, W.W. 2009. Angiospermas em remanescentes de floresta montana no sul da Bahia, Brasil. Biota Neotrop. 9(3):313-348.

BENZING, D.H. 2000. Bromeliaceae. Profile of an adaptive radiation. Cambridge University Press, Cambridge.

BICCA-MARQUES, J.C. 1999. Hand specialization, sympatry, and mixedspecies associations in callitrichines. J. Hum. Evol. 36:349-378. 
CANELA, M.B., PAZ, N.P. \& WENDT, T. 2003. Revision of the Aechmea multiflora complex (Bromeliaceae). Bot. J. Linn. Soc. 143:189-196.

CARDOSO, N. 2008. Frugivoria e dispersão de sementes por mico-leão-dacara dourada (Leontopithecus chrysomelas) na Reserva Biológica de Una - Bahia. MSc Dissertation, Universidade Estadual de Santa Cruz, Ilhéus.

CATENACCI, L. 2008. Ecologia alimentar do mico-leão-da-cara-dourada (Leontopithecus chrysomelas, Callitrichidae, Primates) em áreas degradadas da Mata Atlântica do sul da Bahia. MSc Dissertation, Universidade Estadual de Santa Cruz, Ilhéus.

CATENACCI, L.S., VLEESCHOUWER, K.M.D., NOGUEIRAFILHO, S.L.G. 2009. Seed dispersal by golden-headed lion tamarins Leontopithecus chrysomelas in Southern Bahian Atlantic Forest, Brazil. Biotropica 41:744-750.

CESTARI, C. \& PIZO, M.A. 2008. Utilization of epiphytes by birds in a Brazilian Atlantic forest. Ornitol. Neotrop. 19:97-107.

CESTARI, C. 2009. Epiphyte plants use by birds in Brazil. Oecol. Bras. 13(4):689-712.

FARIA, D.M., LAPS, R.R, BAUMGARTEN, J.E. \& CETRA, M. 2006. Bat and bird assemblages from forests and shade cacao plantations in two contrasting landscapes in the Atlantic Forest of southern Bahia, Brazil. Biodivers. Conserv. 15:587-612.

FISCHER, E.A. \& ARAUJO, A.C. 1995. Spatial organization of a bromeliad community in the Atlantic Rainforest, South-Eastern Brazil. J. Trop. Ecol. 11:559-567.

GALETTI, M. 2002. Seed dispersal of mimetic seeds: parasitism, mutualism, aposematism or exaptation? In Seed dispersal and frugivory: ecology, evolution and conservation (D. Levey, W.R Silva \& M. Galetti, ed.). CABI Publishing, Oxon, p.177-192.

GALETTI, M., PIZO, M.A. \& MORELLATO, L.P.C. 2003. Fenologia, frugivoria e dispersão de sementes. In Métodos de estudos em biologia da conservação emanejo da vida silvestre (L. Cullen, R. Rudran \& C.V. Pádua, ed.). UFPR, Curitiba, p.395-422.

GENTRY, A. \& DODSON, C.H. 1987. Diversity and biogeography of Neotropical vascular epiphytes. Ann. Missouri Bot. Gard. 74:205-233.

GUIDORIZZI, C.E. 2008. Ecologia e comportamento do mico-leão-dacara dourada, Leontopithecus chrysomelas (Kuhl, 1820) (Primates, Callitrichidae), em um fragmento de floresta semidecidual em Itororó, Bahia, Brasil. MSc Dissertation, Universidade Estadual de Santa Cruz, Ilhéus.

GUimarÃeS, P.R., JOsÉ J., GALETTI, M. \& TRIGO J.R. 2003. Quinolizidine alkaloids in Ormosia arborea seeds inhibit predation but not hoarding by agoutis (Dasyprocta leporina). J. Chem. Ecol. 29:1065-1072.
HOWE, H.F. 1993. Aspects of variation in a neotropical seed dispersal system. Plant Ecol. 107-108:149-162.

MORI, S.A., BOOM, B.M. \& PRANCE, G.T. 1981. Distribution patterns and conservation of eastern Brazilian coastal forest tree species. Brittonia 33:233-245

NADKARNI, N. M. \& MATELSON, T.J. 1989. Bird use of epiphyte resources in Neotropical trees. Condor 91:891-907.

PERES, C.A. \& VAN ROOSMALEN, M.G.M. 1996. Avian dispersal of "mimetic seeds" of Ormosia lignivalvis by terrestrial granivores: deception or mutualism? Oikos 75:249-258.

RABOY, B.E. \& DIETZ, J.M. 2004. Diet, foraging, and use of space in wild golden-headed lion tamarins. Am. J. Primatol. 63:1-15.

RABOY, B.E., CHRISTMAN, M.C. \& DIETZ, J.M. 2004. The use of degraded and shade cocoa forests by endangered golden-headed lion tamarins Leontopithecus chrysomelas. Oryx 38(1):75-83.

RABOY, B.E., NEVES, L.G., ZEIGLER, S., SARAIVA, N.A., CARDOSO, N., DOS SANTOS, G.R., BALLOU, J.D. \& LEIMGRUBER, P. 2009. Strength of habitat and landscape metrics in predicting golden-headed lion tamarin presence or absence in forest patches in Southern Bahia, Brazil. Biotropica. 42( 3):388-397.

RYLANDS, A.B. 1989. Sympatric Brazilian callitrichids: the black tuftedear marmoset, Callithrix kuhli, and the golden-headed lion tamarin, Leontopithecus chrysomelas. J. Hum. Evol. 18:679-695.

SAZIMA, M., BUZATO, S. \& SAZIMA, I. 2000. Polinização por beijaflores em Nidularium e gêneros relacionados. In: Bromélias da Mata Atlântica-Nidularium (E.C. Leme, ed.). p.188-195. Hamburg Donnelley Gráfica Editora, Rio de Janeiro.

SIQUEIRA-FILHO, J.A. \& TABARELLI, M. 2006. Bromeliad species of the Atlantic forest of north-east Brazil: Losses of critical populations of endemic species. Oryx 40:1-7.

SMITH, L.B. \& DOWNS, R.J. 1979. Bromeliaceae (Bromelioideae). Flora Neotrop. 14:1493-2142.

SOUSA, G.M., WANDERLEY, M.G.L. \& ALVES, M. 2008. Inflorescence architecture in Brazilian species of Aechmea subgenus Chevaliera (Bromeliaceae - Bromelioideae). Bot. J. Linn. Soc. 158:584-592.

THOMAS, W.M., CARVALHO, A.M., AMORIM, A.A., GARRISON, J. \& ARBELÁEZ, A.L. 1998. Plant endemism in two forests in southern Bahia, Brazil. Biodivers. Conserv. 7(3):311-322.

ZEIGLER, S., FAGAN, W.F., DEFRIES, R. \& RABOY, B.E. 2010. Identifying important forest patches for the long-term persistence of the endangered golden-headed lion tamarin (Leontopithecus chrysomelas). Trop. Conserv. Sci. 3:63-77. 